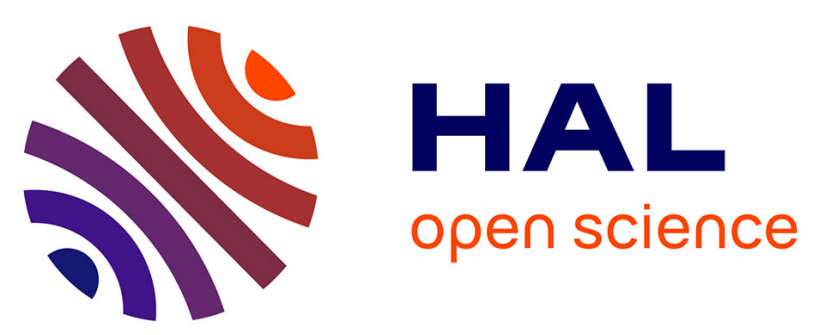

\title{
Physical Properties, Lung Deposition Modeling, And Bioactivity Of Recombinant Gm-Csf Aerosolised With A Highly Efficient Nebulizer
}

Maurizio Luisetti, Philipp Kroneberg, Takuji Suzuki, Zamir Kadija, Bernhard Muellinger, Ilaria Campo, Juliane Gleske, Giuseppe Rodi, William C Zimlich, Francesca Mariani, et al.

\section{To cite this version:}

Maurizio Luisetti, Philipp Kroneberg, Takuji Suzuki, Zamir Kadija, Bernhard Muellinger, et al.. Physical Properties, Lung Deposition Modeling, And Bioactivity Of Recombinant Gm-Csf Aerosolised With A Highly Efficient Nebulizer. Pulmonary Pharmacology \& Therapeutics, 2011, 24 (1), pp.123. 10.1016/j.pupt.2010.08.004 . hal-00721578

\section{HAL Id: hal-00721578 https://hal.science/hal-00721578}

Submitted on 28 Jul 2012

HAL is a multi-disciplinary open access archive for the deposit and dissemination of scientific research documents, whether they are published or not. The documents may come from teaching and research institutions in France or abroad, or from public or private research centers.
L'archive ouverte pluridisciplinaire HAL, est destinée au dépôt et à la diffusion de documents scientifiques de niveau recherche, publiés ou non, émanant des établissements d'enseignement et de recherche français ou étrangers, des laboratoires publics ou privés. 


\section{Accepted Manuscript}

Title: Physical Properties, Lung Deposition Modeling, And Bioactivity Of Recombinant Gm-Csf Aerosolised With A Highly Efficient Nebulizer

Authors: Maurizio Luisetti, Philipp Kroneberg, Takuji Suzuki, Zamir Kadija, Bernhard Muellinger, Ilaria Campo, Juliane Gleske, Giuseppe Rodi, William C Zimlich, Francesca Mariani, Fabio Ferrari, Manuel Frey, Bruce C Trapnell

PII:

$$
\text { S1094-5539(10)00098-2 }
$$

DOI:

$$
\text { 10.1016/j.pupt.2010.08.004 }
$$

Reference: $\quad$ YPUPT 1028

To appear in: Pulmonary Pharmacology \& Therapeutics

Received Date: 24 May 2010

Revised Date: 21 July 2010

Accepted Date: 12 August 2010

Please cite this article as: Luisetti M, Kroneberg P, Suzuki T, Kadija Z, Muellinger B, Campo I, Gleske J, Rodi G, Zimlich WC, Mariani F, Ferrari F, Frey M, Trapnell BC. Physical Properties, Lung Deposition Modeling, And Bioactivity Of Recombinant Gm-Csf Aerosolised With A Highly Efficient Nebulizer, Pulmonary Pharmacology \& Therapeutics (2010), doi: 10.1016/j.pupt.2010.08.004

This is a PDF file of an unedited manuscript that has been accepted for publication. As a service to our customers we are providing this early version of the manuscript. The manuscript will undergo copyediting, typesetting, and review of the resulting proof before it is published in its final form. Please note that during the production process errors may be discovered which could affect the content, and all legal disclaimers that apply to the journal pertain. 


\section{PHYSICAL PROPERTIES, LUNG DEPOSITION MODELING, AND}

\section{BIOACTIVITY OF RECOMBINANT GM-CSF AEROSOLISED WITH A}

\section{HIGHLY EFFICIENT NEBULIZER}

Maurizio Luisetti ${ }^{1 \S}$, Philipp Kroneberg ${ }^{2}$, Takuji Suzuki ${ }^{3}$, Zamir Kadija ${ }^{1}$, Bernhard Muellinger ${ }^{2}$, Ilaria Campo ${ }^{1}$, Juliane Gleske ${ }^{2}$, Giuseppe Rodi ${ }^{4}$, William C Zimlich ${ }^{2}$, Francesca Mariani ${ }^{1}$, Fabio Ferrari $^{5}$, Manuel Frey ${ }^{2}$, Bruce C Trapnell ${ }^{3}$

${ }^{1}$ Laboratory of Biochemistry and Genetics, Respiratory Disease Unit, ${ }^{4}$ Intensive Care Unit, ${ }^{5}$ Dept of Biochemistry “A Castellani”, IRCCS San Matteo Hospital Foundation \& University of Pavia, Italy; ${ }^{2}$ Activaero GmbH, Gemünden/Wohra, Germany; ${ }^{3}$ Cincinnati Children's Hospital Medical Center, Cincinnati, OH, USA

${ }^{\S}$ Corresponding author: Dr Maurizio Luisetti, SC Pneumologia, Dipartimento Cardiotoracovascolare, Fondazione IRCCS Policlinico San Matteo, Università di Pavia, 27100 Pavia, Italy. Phone +390382 423131 FAX +390382 422267

Running title : $\quad$ Aerosolised GM-CSF 


\begin{abstract}
Pulmonary alveolar proteinosis (PAP) is a rare condition characterized by the accumulation of lipoproteinaceous material within air spaces. Although whole lung lavage is the current standard of care, recent advances in our understanding of PAP pathophysiology suggest that the disorder may benefit from inhalation of recombinant granulocyte-macrophage colony-stimulating factor (rGMCSF). The aim of this study was to determine the physical properties and bioactivity of rGM-CSF aerosolized by the highly efficient AKITA² APIXNEB® nebulizer system. The physical properties of aerosolised rGM-CSF were investigated in terms of droplet size, output and output rate by laser diffraction and gravimetrical analysis. Lung deposition was assessed using deposition modeling (ICRP). Molecular mass before and after aerosolisation was determined by SDS-PAGE, while the bioactivity of rGM-CSF was evaluated by measuring the GM-CSF-stimulated increase in pSTAT-5 using mAM-hGM-R cells. Ninety-six \% of the rGM-CSF filling dose was aerosolized with the Akita $^{2}$ Apixneb $®$ nebulizer system. Particle size was highly reproducible, and the amount deposited within the lung was $80.35 \%$ of the delivered dose. The aerosolisation did not alter the molecular structure of rGM-CSF, nor its ability to stimulate the pSTAT-5, which increased by $99.5 \%$, similar to values for rGM-CSF prior to aerosolisation. We conclude that the highly efficient AKITA ${ }^{2}$ APIXNEB ${ }^{\circledR}$ nebulizer system is likely to efficaciously deliver rGM-CSF to the airways of patients with autoimmune PAP.
\end{abstract}




\section{Introduction}

Pulmonary alveolar proteinosis (PAP) is a rare condition characterized by the accumulation of lipoproteinaceous material within air spaces, and occurs in different clinical forms [1]. The presence of autoantibodies (Abs) neutralizing granulocyte macrophage colony-stimulating factor (GM-CSF) [2] and the reproduction of the pathologic disease manifestations by passive transfer of human Abs to primates [3] has permitted the reclassification of this condition to "autoimmune PAP", the most frequent clinical form of PAP; previously it was referred to as "idiopathic" or "acquired" PAP [1]. These findings have opened the way to novel therapeutic scenarios. 
The current standard of care for PAP is whole lung lavage (WLL), which results in the complete and durable resolution of PAP lung abnormalities in a percentage ranging from 20 to 70 of lavaged patients [4-5]. In addition, WLL is a highly invasive procedure, and even though complications are infrequent it requires prolonged anesthesia. The evidence that autoimmune PAP is caused by a disruption in GM-CSF signaling, has prompted investigations with recombinant GM-CSF (rGMCSF) supplementation. A small series of PAP patients have been treated with rGM-CSF either subcutaneous (s.c.) or by inhalation, the overall response rate was slightly better by the latter route [6] . To date, no side effects, even for prolonged treatments, have been reported. Clearly, this therapeutic option, although very promising, requires further verification, in larger randomized trials

A clinical trial, aimed at maximizing the therapeutic outcome in PAP patients, has been recently approved [7] . The objective of the trial is to demonstrate the superiority of WLL followed by inhaled rGM-CSF vs WLL alone to obtain sustained resolution of lung abnormalities in autoimmune PAP patients. To optimize drug delivery, we decided to utilize the AKITA ${ }^{2}$ APIXNEB® apparatus, a vibrating mesh nebulizer with controlled breathing and aerosol pulse technology. A series of experiments, preliminary to the trial, were therefore planned to investigate the particle size distribution and output. In addition, an important variable to be determined was the retention of rGM-CSF biological activity after aerosolisation. A series of experiments were therefore planned to investigate this aim. In this study we demonstrate the highly effective performance of the Akita $^{2}$ Apixneb® nebulizer system with the rGM-CSF formulation. In addition, aerosolisation does not alter the molecular mass or the biological activity of rGM-CSF.

\section{Methods}


The rGM-CSF (Sargramostim, Leukine ${ }^{\circledR}$ ) used in all experiments was a lyophilized preparation (250 $\mu \mathrm{g} /$ vial preservative-free powder) purchased from Bayer $\mathrm{HC}$ (Seattle, WA), and kept at $4{ }^{\circ} \mathrm{C}$ until needed, and then dissolved in $1 \mathrm{ml}$ saline. In all experiments, the AKITA ${ }^{2}$ APIXNEB® nebulizer handset (Activaero, Gemünden, Germany) was equipped with a Smart Card with the following configuration : inhalation volumes : $1500 \mathrm{ml}$; bolus width : $1250 \mathrm{ml}$; bolus depth : 1500 $\mathrm{ml}$; flow rate : $15 \mathrm{~L} / \mathrm{min})$.

\section{Characterization studies}

Unless specified otherwise, all experiments were conducted in triplicate.

- Particle size distribution. This method was used to characterize the droplet size distribution of the nebulized aerosol for different nebulizer systems. For the measurements, a laser diffraction particle sizer (Sympatec) was used. The aerosol was sent into a closed conditioned channel, where a laser beam illuminated the aerosol. When the laser light interacts with the aerosol particles the light is diffracted, reflected and refracted and a characteristic light spectrum is generated (fig.1). A multi-element sensor detected the light spectrum at different angles and the droplet size distribution was calculated by using Mie-theory. For each experiment, the nebulizer was filled with $250 \mu \mathrm{g}$ rGM-CSF dissolved in $1 \mathrm{ml}$ sterile saline. The measurements were conducted at room temperature, but the temperature of the measurement chamber was cooled to $18{ }^{\circ} \mathrm{C}$. The droplet size distribution $[\mathrm{x} 50(\mathrm{VMD})$ : volume median diameter $(\mu \mathrm{m}$; the geometric particle diameter of an aerosol); GSD: geometric standard deviation (value describing the width of a lognormal particle size distribution); $\mathrm{C}_{\mathrm{opt}}$ : Optical concentration (\%)] was evaluated by the Sympatec Windox4-Software by using the Mie-Theory.

- Output and output rate. With this method, total output for each nebulizer was measured. Delivered dose was determined by gravimetrical analysis. Therefore, the nebulizer weight was measured with a precision balance before and after filling with a pipette. The continuous output 
rate was calculated from the cumulative nebulization time per treatment which was recorded and noted, as well as the total amount of nebulized material.

- Lung deposition modeling. Lung dose was calculated using the International Commission for Radiological Protection (ICRP) Deposition Model [8-10]. The inhalation flow rate was $15 \mathrm{~L} / \mathrm{min}$ for the $\mathrm{AKITA}^{2}$ APIXNEB ${ }^{\circledR}$ nebulizer. For the deposition calculations, laser diffraction results were used.

\section{Biological Activity}

For this set of experiments, rGM-CSF was aerosolized with the AKITA² APIXNEB ${ }^{\circledR}$ nebulizer, collected in a sterile glass bottle, kept on ice where it condensed; it was then harvested, divided into aliquots and kept frozen at $-20^{\circ} \mathrm{C}$ until needed. A dissolved rGM-CSF sample, which was not aerosolized served as control.

- Determination of the molecular mass. The molecular mass of samples before and after aerosolisation was evaluated by submitting aliquots of rGM-CSF to SDS-polyacrilamide gel electrophoresis (SDS-PAGE).

- Concentration of rGM-CSF pre-and post-aerosolization. The rGM-CSF concentration in samples before and after aerosolisation was determined by a commercially available ELISA kit (R\&D Systems)

- Biological activity of rGM-CSF pre-and post-aerosolization. The biological activity of rGMCSF before and after aerosolisation was determined by measuring the GM-CSF-stimulated increase in phosphorylated signal transducer and activator of transcription 5 (pSTAT-5). This indicator of GM-CSF signaling utilizes mAM-hGM-R cells, which is a GM-CSF-deficient murine cell line (mAM cells) [11] retrovirally expressing functional human GM-CSF receptors. This novel genetically modified cell line exhibits cytokine-specific, dose-and time-dependent GM-CSF signaling responses. Briefly, aliquots of pre- and post- aerosolized rGM-CSF samples were diluted 1:25,000 and incubated with mAM-hGM-R cells for 15 min, after which cells were 
lysed and evaluated by western blotting using the antibodies of pSTAT5 (Milipore) and STAT5 (SantaCruz) as described previously [12]. Phosphorylation of STAT5 was quantified by PathScan-STAT5(Y694) Sandwich ELISA Kit (Cell Signaling Technology). Phosphorylation of STAT5 by post-aerosolised samples was calculated as \% phosphorylation by pre-aerosolised samples. GM-CSF samples of a known concentration were used as calibration standards [12].

\section{Results}

Particle size distribution, output and output rate. Particle size distribution, analyzed by laser diffraction, showed a volume median diameter (VMD) of $4.31 \mu \mathrm{m} \pm 0.11$ (mean $\pm \mathrm{SD}$; range 4.28 - $4.43 \mu \mathrm{m})$. The geometric standard deviation (GSD) of all measurements showed the mean value $1.58 \pm 0.03$. The output dose, determined by gravimetrical analysis, was estimated as $95.71 \% \pm$ 0.018 for a filling dose of $1 \mathrm{~mL}$. Finally, the continuous output rate observed was $1.043 \mathrm{~mL} / \mathrm{min}$. These data are reported in detail in tables 1-3.

Lung deposition modeling. For the detected particle size and the specified breathing pattern, the estimated overall lung deposition in percentage of delivered dose was $80.35 \%$. Interestingly, approximately $50 \%$ of the delivered dose was calculated to reach the alveolar spaces (table 4). Since, according to the dose calculation, the estimated lung deposition, from a starting volume of $250 \mu \mathrm{g}$, was $192.3 \mu \mathrm{g}$. We estimated that approximately $96 \mu \mathrm{g}$ of rGM-CSF would come into contact with the GM-CSF neutralizing Abs present in the alveolar spaces of the PAP subject.

Biological activity. In contrast with the output method, the collection system we used to harvest the post-aerosolization samples, yielded a mean recovery, in two different experiments, of $0.625 \pm$ $0.020 \mu \mathrm{l}$ from the initial $1 \mathrm{ml}$ volume. Nevertheless, the concentration of rGM-CSF determined by ELISA in the post-aerosolisation samples was respectively $94.1 \%$ and $95 \%$, of the preaerosolisation samples. This would suggest that this method yielded a significant concentration in the aerosol volume, likely due to evaporation, with no rGM-CSF loss. The ELISA determination 
substantially confirmed the output dose determination, described above. In addition, the SDSPAGE experiments showed that the aerosolisation did not alter the structure of rGM-CSF. In fact, the three major bands corresponding to the rGM-CSF were identical in aspect and molecular mass before and after aerosolisation (figure 2). The three major rGM-CSF bands are consistent with the description provided by the manufacturer that Leukine ${ }^{\circledR}$ is “...characterised by 3 primary molecular species having molecular masses of 19,500, 16,800, and 15,500 daltons..” [13] . To evaluate GMCSF bioactivity, mAM-hGM-R cells were incubated with Pre- or Post- aerosolized rGM-CSF samples after dilution 25,000 and were evaluated by detecting the phosphorylation of STAT5 (pSTAT5), which is one of the GM-CSF receptor signaling molecules. Western blotting of pSTAT5 showed the similar bioactivity in Pre- and Post- aerosolized rGM-CSF (Figure 3A). Quantification of pSTAT5 by ELISA demonstrated that the mean ( \pm S.E.M.) increase in pSTAT5 in postaerosolization aliquots was $99.5 \pm 4.1 \%$ of pre-aerosolization $(n=5 ; P=0.872)$ (Figure $3 B$ ), indicating that aerosolization did not significantly alter GM-CSF bioactivity

\section{Discussion}

The experiments described in this paper provide important information on nebulized GM-CSF. These data are essential for the design of a trial to provide local delivery of GM-CSF in patients with autoimmune PAP. In fact, GM-CSF supplementation in patients with PAP characterized by the presence of anti-GM-CSF Abs was first delivered s.c. with variable results. Over the last 14 years, approximately 50 PAP patients have been treated with rGM-CSF by this route [14-17], with the following results: 1) improvement was observed in about $50 \%$ of patients; 2) a variable response among patients; 3) response depended on dose and duration of therapy, and 4) a lag of about eight weeks was necessary before a response was detected [6]. Since it is conceivable that the alveolar space is the site of GM-CSF signal disruption leading to the impairment of surfactant catabolism in 
autoimmune PAP, then it is reasonable to propose that local GM-CSF supplementation would result in better treatment outcome. After a preliminary, but interesting report showing that aerosol delivery of GM-CSF in three PAP patients resulted in a decrease in GM-CSF neutralizing capacity in the lungs [18], a paper including 12 PAP patients treated with $250 \mathrm{mg}$ b.i.d. aerosolized GMCSF for varying time periods, showed a positive response in $91 \%$ of the subjects [19]. In a more recent, well designed Japanese study, including a run-in period, followed by an induction dose, and finally a maintenance dose, the response rate in 35 PAP patients was $68 \%$ [20]. Taken together, the above reported data seem to suggest the superiority of the inhalation route $v s$ the subcutaneous one.

Interestingly, these results were achieved with an aerosol apparatus (LC Plus - PARI, Midlothian, VA), whose performance differs from that of the AKITA $^{2}$ APIXNEB ${ }^{\circledR}$ herein utilized. We therefore considered it a priority to perform a preliminary study on the characteristics of rGM-CSF aerosolized with the apparatus intended for use in the future clinical trial. This apparatus combines a vibrating mesh nebulizer with a computerized compressor to control both inhalation flow rate and inhaled volume [21]. In recent studies, the apparatus has been used to investigate the deposition of radiolabelled alpha1-antitrypsin (AAT) in healthy controls, and patients with either alpha1antitrypsin deficiency or cystic fibrosis (CF) [22], and the effect of inhaled AAT on the inflammatory process in the airways of patients with CF [23] . Taken together, these studies suggest that the total lung deposition of AAT is approximately $70 \%$ of the filling dose, irrespective of the degree of lung function impairment, and that this resulted, in short term treatment, and a clear reduction in signs of airway inflammation in CF patients. The AKITA² APIXNEB® equipment has also been used to aerosolize all-trans retinoic acid in a single case of severe emphysema, with improvement in lung function and inflammatory parameters [24] . 
Data herein presented seem to support the concept that the AKITA ${ }^{2}$ APIXNEB $®$ is an apparatus capable of providing optimal delivery of rGM-CSF to the air spaces of PAP patients. In fact, the particle sizing experiments showed highly reproducible particle sizes for rGM-CSF, with a $0.2 \mu \mathrm{m}$ maximum difference within three measurements. Such a low variation in particle size will not have a significant effect on drug delivery. The effective range of emitted dose was in the typical range for the nebulizer system used. The available dose at the mouthpiece was about $96 \%$ of the filling dose, thus suggesting that aerosol generation by the device is highly effective for the rGM-CSF formulation. Interestingly, the emitted dose, evaluated by gravitational analysis, was confirmed at the same rate by an ELISA test, in a different laboratory. Lung deposition modeling was performed to calculate the amount that will deposit within the patient's lungs. For deposition modeling the ICRP deposition model was selected, which is a semi empirical deposition model [8-10] . Calculated lung deposition values in percentage of delivered dose in this study showed results similar to those reported in the literature [10]. In particular the results achieved showed a highly effective lung deposition for the rGM-CSF formulation : assuming an exhaled rate of $7.63 \%$, and an extrathoracic deposition of $12.02 \%$, the lung deposition of the particles would account for $80.35 \%$ of the delivered dose, of which $30.48 \%$ is at the tracheo-bronchial level and $49.94 \%$ at the alveolar level. If we assume that the delivered dose, from a filling dose of $250 \mu \mathrm{g}$, is $239 \mu \mathrm{g}$, then the dose of rGM-CSF directly delivered to the alveolar spaces would be $96 \mu \mathrm{g}$ (table 4).

However, in spite of the above described encouraging results from physical properties and deposition modeling investigation, it must bear in mind that the presence in vivo of lipotroteinaceous material in the airspaces of patients with PAP might alter the GM-CSF deposition, thus making the expected performance less efficient.

A second important achievement of this study was the demonstration that not only the delivery pattern, but also the biological activity of rGM-CSF was maintained with the AKITA ${ }^{2}$ 
APIXNEBb® apparatus. We evidenced that, after aerosolisation, the rGM-CSF showed the same electrophoretic migration pattern as before aerosolisation (figure 2). The three major rGM-CSF bands, detected at 20,600,17,800, and 16,500 daltons are consistent with the description provided by the manufacturer [13] .

More importantly, aerosolized rGM-CSF fully retained its biological activity after aerosolisation. In fact, the aerosolisation of the drug through AKITA $^{2}$ APIXNEB ${ }^{\circledR}$ did not alter either its molecular mass or its biological activity, which is almost fully retained, as suggested by the ability to activate the signal transduction in the cell line expressing the human GM-CSF receptor.

No comparative studies have been performed, to the best of our knowledge, on the performance of both the $\mathrm{AKITA}^{2}$ APIXNEB ${ }^{\circledR}$ device and the Pari LC-plus nebulizer, the latter having been used to aerosolize rGM-CSF to PAP patients in the above discussed papers [18-20]. The only available paper compared the effects of inhaled tobramycin in cystic fibrosis patients using an older version of AKITA [25]. In this paper, it was shown that the AKITA significantly reduced the amount of drug required, the inhalation time, and the variability of dosage. Thus we speculate that the performance of AKITA² APIXNEB® should be at least not inferior.

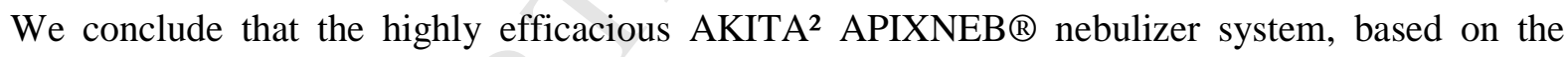
effective in vitro performance and the complete preservation of the structure and bioactivity of the aerosolized drug, is likely to produce positive results when applied to the in vivo delivery of rGMCSF to the airways of autoimmune PAP patients.

\section{Authors contribution}


ML and BCT designed the study and drafted the paper; WCZ, BM, JG, PK and MF designed, performed, and collected data on the aerosolized rGM-CSF physical characterization (particle sizing, output rate and lung deposition modeling); TS, ZK, IC, FM, FF and GR designed, performed, and collected data on the bioactivity experiments.

\section{Acknowledgements}

This study was supported by the AIFA (Italian Agency for Medicines) project FARM7MCPK4.

\section{References}


1. Trapnell BC, Whittset JA, Nakata K. Pulmonary alveolar proteinosis. N Engl J Med 2003; 349: $2527-2539$.

2. Kitamura T, Tanaka N, Watanabe J, Uchida K, Kanegasaki S, Yamada Y, Nakata K. Idiopathic pulmonary alveolar proteinosis as an autoimmune disease with neutralizing antibody against granulocyte/macrophage colony-stimulating factor. J Exp Med 1999; 190: 875-880.

3. Sakagami T, Uchida K, Suzuki T, Carey BC, Wood RE, Wert SE, Whitsett JA, Trapnell BC, Luisetti M. Human GM-CSF autoantibodies and pulmonary alveolar proteinosis. N Engl J Med 2009; 361: 2679-2681.

4. Seymour JF, Presneill JJ. Pulmonary alveolar proteinosis. Progress in the first 44 years. Am J Respir Crit Care Med 2002; 166: 215-235.

5. Beccaria M, Luisetti M, Rodi G, Corsico A, Zoia MC, Colato S, Pochetti P, Braschi A, Pozzi E, Cerveri I. Long term durable benefit after whole lung lavage in pulmonary alveolar proteinosis. Eur Respir J 2004; 23: 526-531.

6. Luisetti M, Trapnell BC. Pulmonary alveolar proteinosis. In: Interstitial Lung Disease $5^{\text {th }}$ Edition. Edited by Schwarz MI, King TE Jr (in press).

7. Whole Lung Lavage (WLL)/Inhaled Granulocyte-macrophage Colony-stimulating Factor (GM-CSF) in Autoimmune Pulmonary Alveolar Proteinosis (PAP). ClinicalTrial.gov Identifier : NCT00901511.

8. International Commission on Radiological Protection. Human respiratory model for radiological protection. Ann ICRP 1994; 24: 1-120. 
9. Köbrich R, Rudolf G, Stahlhofen W. A mathematical model of mass deposition in man. Ann Occup Hyg 1994; 38: 15-23.

10. Fleming JS, Epps BP, Conway JH, Martonen TB. Comparison of SPECT aerosol deposition data with a human respiratory tract model. J Aerosol Med 2006; 19: 268-278.

11. Shibata Y, Berclaz PY, Chroneos ZC, Yoshida M, Whitsett JA, Trapnell BC. GM-CSF regulates alveolar macrophage differentiation and innate immunity in the lung through PU.1. Immunity 2001; 15: 557-567.

12. Suzuki T, Sakagami T, Rubin BK, Nogee LM, Wood RE, Zimmerman SL, Smolarek T, Dishop MK, Wert SE, Whitsett JA, Grabowski G, Carey BC, Stevens C, van der Loo JC, Trapnell BC. Familial pulmonary alveolar proteinosis caused by mutations in CSF2RA._J Exp Med. 2008; 205:2703-10.

13. Bayer HealthCare Pharmaceuticals. Leukine ${ }^{\circledR}$ Sargramostim. A recombinant GM-CSF yeast-expressed. Data on file Revision Date 4/08.

14. Seymour JF, Dunn AR, Vincent JM, Presneill JJ, Pain MC. Efficacy of granulocytemacrophage colony-stimutaling-factor in acquired alveolar proteinosis. N Engl J Med 1996; 335: $1924-1925$.

15. Kavuru MS, Sullivan EJ, Piccin R, Thomassen RJ, Stoller JK. Exogenous granulocytemacrophage colony-stimulating factor administration for pulmonary alveolar proteinosis. Am J Respir Crit Care Med 2000; 161: 1143-1148.

16. Seymour JF, Presneiil JJ, Schoch OD, Downie GH, Moore PE, Doyle IR, Vinceny JM, Nakata K, Kitamura T, Langton D, Pain MC, Dunn HR. Therapeutic efficacy of granulocyte-macrophage colony-stimulating-factor in patients with idiopathic acquired pulmonary alveolar proteinosis. Am J Respir Crit Care Med 2001, 163: 524- 531. 
17. Ventaketashiah SB, Yan TD, Bonfield TL, Thomassen MJ, Meziane M, Czich C, Kavuru MS. An open-label trial of granulocyte macrophage colony stimulating factor therapy for moderate symptomatic pulmonary alveolar proteinosis. Chest 2006; 130:227-237.

18. Tazawa R, Hamano E, Arai T, Ohta H, Ishimito O, Uchida K, Watanabe M, Saito J, Takeshita M, Hirabayashi Y, Ishige I, Eishi E, Hagiwara K, Ebina M, Inoue Y, Nakata K, Nukiwa T. Granulocyte-macrophage colony-stimulating factor and lung immunity in pulmonary alveolar proteinosis. Am J Respir Crit Care Med 2005; 171: 1142-1149.

19. Wylam ME, Ten R, Prakash UBS, Nadrous HF, Clawson ML, Anderson PM. Aerosol granulocyte-macrophage colony-stimulating factor for pulmonary alveolar proteinosis. Eur Respir J 2006; 27: 585-593.

20. Tazawa R, Trapnell BC, Inoue Y, Arai T, Takada T, Nasuhara Y, Hizawa N, Kasahara W, Tatsumi K, Hojo M, Ishii H, Yokoba M, Tanaka N, Yamaguchi E, Eda R, Tsuchihashi Y, Morimoto K, Akira M, Terada M, Ohtsuka J, Ebina M, Kaneko C, Nukiwa T, Krischer JP, Akazawa K, Nakata K. Inhaled granulocyte-macrophage colony-stimulating factor as therapy for pulmonary alveolar proteinosis. Am J Respir Crit Care Med 2010 (in press).

21. Scheuch G, Meyer T, Mullinger B. Controlled inhalation improves peripheral deposition. J Aerosol Sci 2001; 14: 388.

22. Brand P, Schulte M, Wencker M, Herpich CH, Klein G, Hanna K, Meyer T. Lung deposition of $\alpha 1$-proteinase inhibitor in cystic fibrosis and $\alpha 1$-antitrypsin deficiency. Eur Respir J 2009; 34: 354-360.

23. Griese M, Latzin P, Kappler M, Weckerle K, Hienzlmaier T, Bernhardt T, Hartl D. $\alpha 1$ antitrypsin inhalation reduces airway inflammation in cystic fibrosis patients. Eur Respir $\mathbf{J}$ 2007; 29: $240-250$.

24. Frankeberger M, Heimbek I, Moller W, Mamidi S, Kassner G, Pukelshiem K, Wjst M, Neiswirth M, Kroneberg P, Lomas D, Hallsal D, Iadarola P, Fertl A, Haussinger K, Ziegler- 
Heitbrock L. Inhaled all-trans retinoic acid in an individual with severe emphysema. Eur Respir J 2009; 34: 1487-1489.

25. Dopfer R, Brand P, Mullinger B, Hunger T, Haussermann S, Meyer T, Scheuch G, Siekmeier R. Inhalation of tobramycin in patients with cystic fibrosis : comparison of two methods. J Physiol Pharmacol 2007; 58 (Suppl 5): 141 -154.

\section{FIGURE LEGENDS}


Figure 1 - Schematic laser diffraction setup

Figure 2 - $16 \%$ SDS-PAGE (1 mm). Lane 1: Molecular markers. Lanes 2 and 4 : Pre-aerosolization sample. Lanes 3 and 5: Post-aerosolization sample. Denaturing Loading Buffer (LB) with SDS, not reducing. Lanes 2 and 3: two part of sample and one part of LB. Lanes 4 and 5: one part of sample and one part of LB. A total of $30 \mu 1$ was loaded in each well. Staining with Coomassie solution.

Figure 3 - A- Functional assay of rGM-CSF. mAMhGMR cells were incubated with different concentrations of native rGM-CSF $(0,1 ; 1 ; 10 \mathrm{ng} / \mathrm{ml}, 15 \mathrm{~min})$ and with rGM-CSF before (1 5) and after (6 10) aerosolization through AKITA² APIXNEB®. Western analysis was then performed to detect phosphorylated STAT5 (pSTAT5) and total STAT5 (STAT5).

B- rGM-CSF signaling measured by pSTAT5 ELISA, before $(\mathrm{N}=5)$ and after $(\mathrm{N}=5)$ aerosolization through AKITA² APIXNEB®. 
Table 1- Results of particle sizing experiments

\begin{tabular}{|c|c|c|c|c|c|c|c|c|c|}
\hline $\begin{array}{l}\text { Measurement } \\
\text { No. }\end{array}$ & $\begin{array}{l}\text { Nebulizer } \\
\text { No. }\end{array}$ & $\begin{array}{l}\text { Filling } \\
\text { Volume } \\
{[\mathrm{mL}]}\end{array}$ & $\begin{array}{l}\text { VMD } \\
{[\mu \mathrm{m}]}\end{array}$ & GSD & $\begin{array}{l}\mathbf{c}_{\text {opt }} \\
{[\%]}\end{array}$ & $\begin{array}{l}\text { VMD } \\
\text { Mean } \\
\text { Value } \\
{[\mu \mathrm{m}]}\end{array}$ & $\begin{array}{l}\text { VMD } \\
\text { SD }\end{array}$ & $\begin{array}{l}\text { GSD } \\
\text { Mean } \\
\text { Value }\end{array}$ & $\begin{array}{l}\text { GSD } \\
\text { SD }\end{array}$ \\
\hline 1.1 & $\begin{array}{r}\text { GMP- } \\
01\end{array}$ & 1 & 4.4 & 1.6 & 14. & & & & \\
\hline 1.2 & $\begin{array}{r}\text { GMP- } \\
01\end{array}$ & 1 & 4.2 & 1.5 & 17. & 4.31 & 0.1 & & \\
\hline 1.3 & GMP-01 & 1 & 4.28 & 1.57 & 17.13 & & & & \\
\hline
\end{tabular}


Table 2- Output measurement results

\begin{tabular}{|c|c|c|c|c|c|c|c|c|}
\hline $\begin{array}{l}\text { Measurement } \\
\text { No. }\end{array}$ & $\begin{array}{l}\text { Nebulizer } \\
\text { No. }\end{array}$ & $\begin{array}{l}\text { Filling } \\
\text { Vol [mL] }\end{array}$ & $\begin{array}{l}\text { Emitted } \\
\text { dose }[\mathrm{mL}]\end{array}$ & $\begin{array}{l}\text { Mean } \\
\text { Emitted } \\
\text { dose }[\mathrm{mL}]\end{array}$ & SD & $\begin{array}{l}\text { Emitted } \\
\text { dose [\% } \\
\text { of filling] }\end{array}$ & $\begin{array}{l}\text { Mean } \\
\text { Emitted } \\
\text { dose }\end{array}$ & SD \\
\hline 2.1 & GMP-01 & 1 & 0.95 & \multirow{3}{*}{0.956} & \multirow{3}{*}{0.073} & $97.7 \%$ & \multirow{3}{*}{$95.71 \%$} & \multirow{3}{*}{0.018} \\
\hline 2.2 & GMP-01 & 1 & 0.95 & & & $95.4 \%$ & & \\
\hline 2.5 & GMP-01 & 1 & 0.96 & & & $94.1 \%$ & & \\
\hline
\end{tabular}


Table 3 - Calculated continuous output rate

\begin{tabular}{|c|c|c|c|c|c|c|c|c|}
\hline $\begin{array}{l}\text { Measurement } \\
\text { No. }\end{array}$ & Nebulizer No. & $\begin{array}{l}\text { Filling } \\
\text { Vol } \\
{[\mathrm{mL}]}\end{array}$ & $\begin{array}{l}\text { Emitted } \\
\text { dose }[\mathrm{mL}]\end{array}$ & $\begin{array}{l}\text { No. of } \\
\text { breaths }\end{array}$ & $\begin{array}{l}\text { Nebulization } \\
\text { time per } \\
\text { breath [s] }\end{array}$ & $\begin{array}{l}\text { Calculated } \\
\text { output rate } \\
{[\mathrm{mL} / \mathrm{min}]}\end{array}$ & $\begin{array}{l}\text { Mean output } \\
\text { rate } \\
{[\mathrm{mL} / \mathrm{min}]}\end{array}$ & SD \\
\hline 2.1 & GMP-01 & 1 & 0.95 & 11 & 5 & 1.041 & \multirow{3}{*}{1.043} & \multirow{3}{*}{0.008} \\
\hline 2.2 & GMP-01 & 1 & 0.95 & 11 & 5 & 1.037 & & \\
\hline 2.3 & GMP-01 & 1 & 0.96 & 11 & 5 & 1.052 & & \\
\hline
\end{tabular}


Table 4- Results from lung deposition modeling in \% of delivered dose and deposited drug amount

AKITA $^{2}$ APIXNEB

Regional Deposition of Particles

Extrathoracic Deposition $\quad \% \quad 12.02$

\begin{tabular}{lll}
\hline Tracheobronchial Deposition & $\%$ & 11.09 \\
\hline Bronchial
\end{tabular}

\begin{tabular}{llr}
\hline Bronchial Deposition & $\%$ & 19.32 \\
\hline Alveolar
\end{tabular}

\begin{tabular}{llr}
\hline Alveolar Deposition & $\%$ & 49.94 \\
\hline
\end{tabular}

\begin{tabular}{lll}
\hline Exhaled & $\%$ & 7.63 \\
\hline
\end{tabular}

Lung Deposition

$\begin{array}{lll}(=\text { Tracheal }+ \text { Bronchial }+ \text { Alveolar }) & \% & \mathbf{8 0 . 3 5}\end{array}$

Dose Calculation

\begin{tabular}{llr}
\hline Filled Dose & $\mu \mathrm{g}$ & $250 \mu \mathrm{g}$ \\
\hline Delivered Dose & $\mu \mathrm{g}$ & $239 \mu \mathrm{g}$ \\
\hline
\end{tabular}

Lung Deposition $\mu \mathrm{\mu g}$

(no evaporation assumed)

$192.3 \mu \mathrm{g}$ 


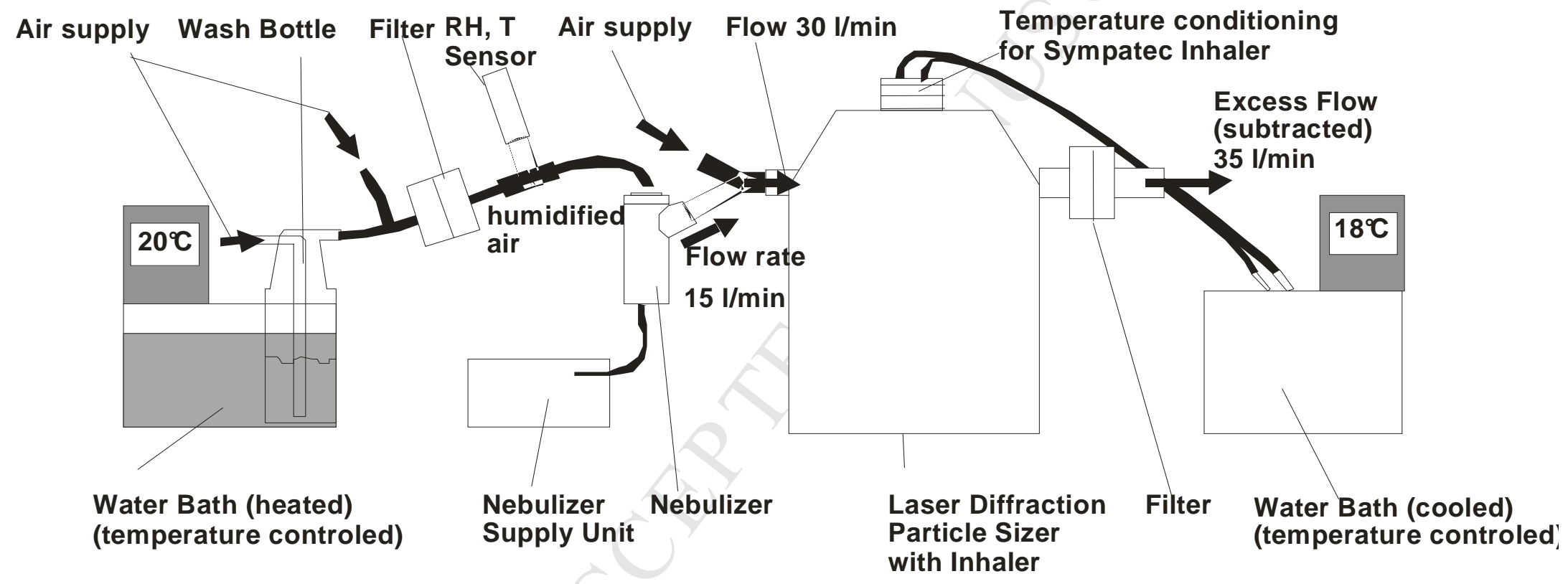




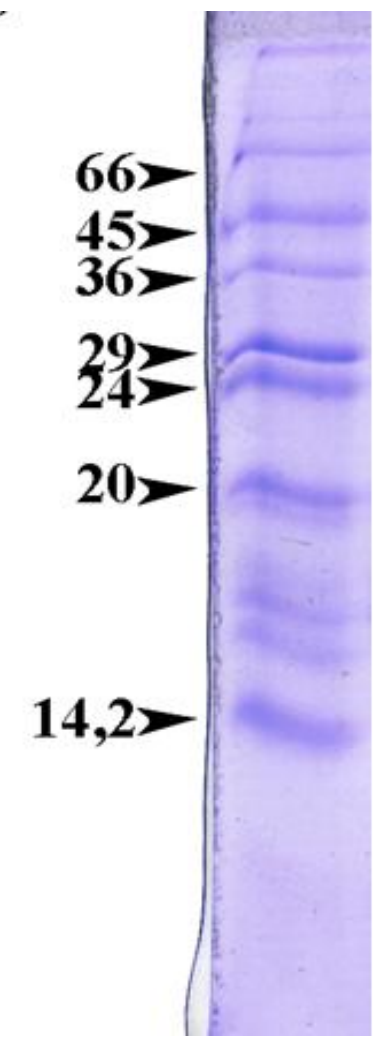

1

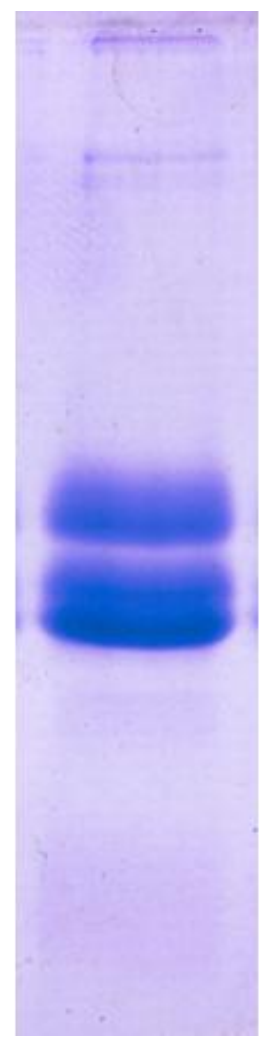

2

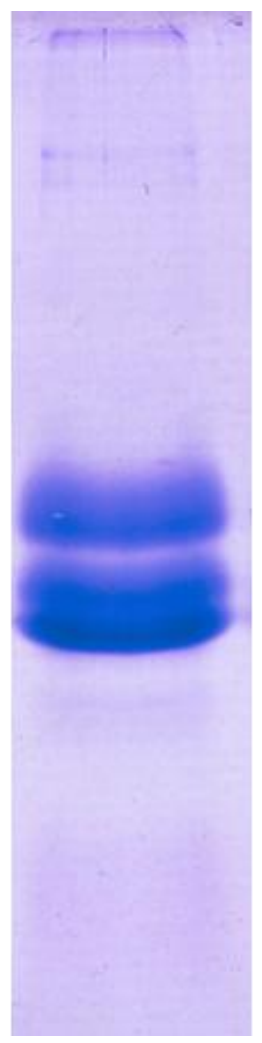

3

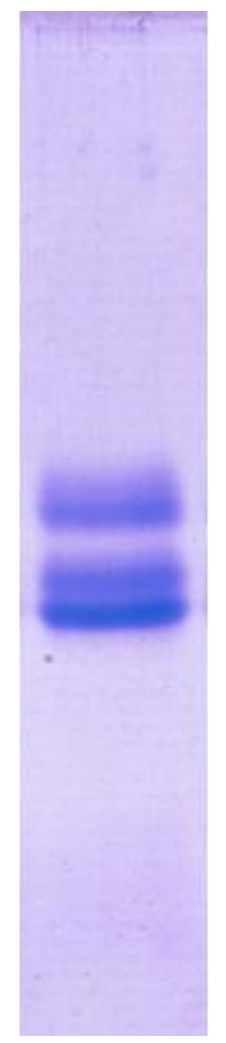

4

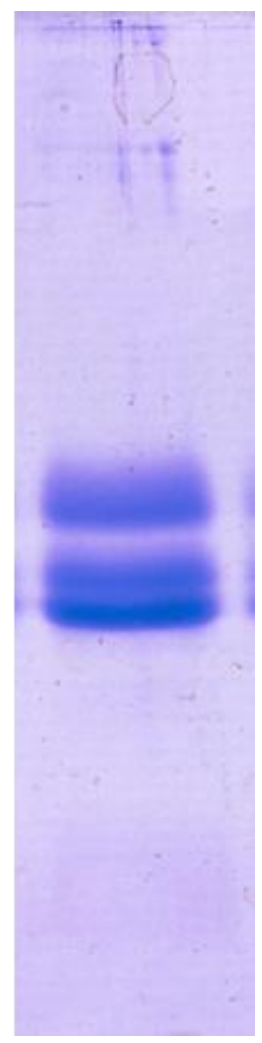

5 
Functions of GM-CSF samples

A
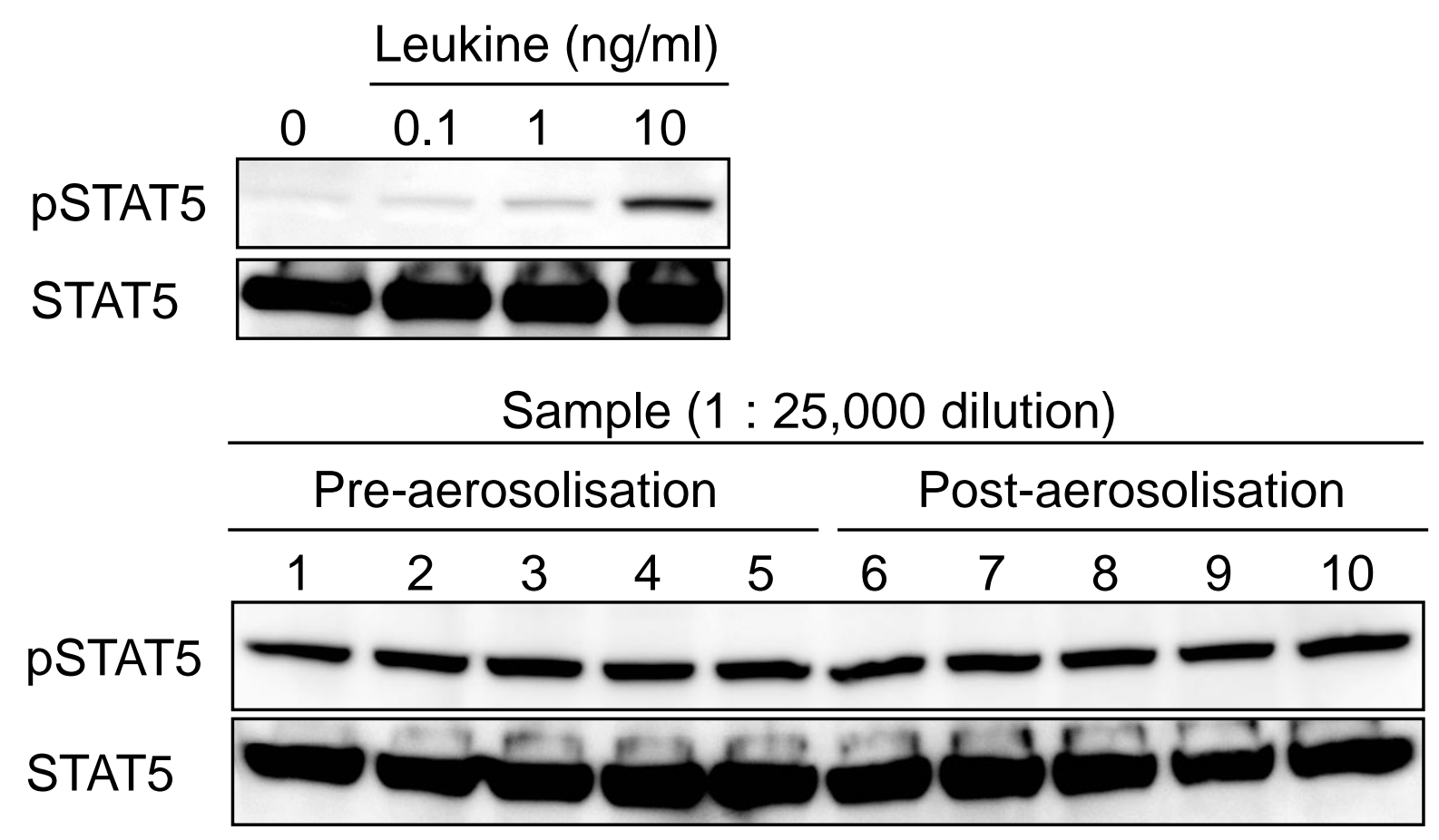

B

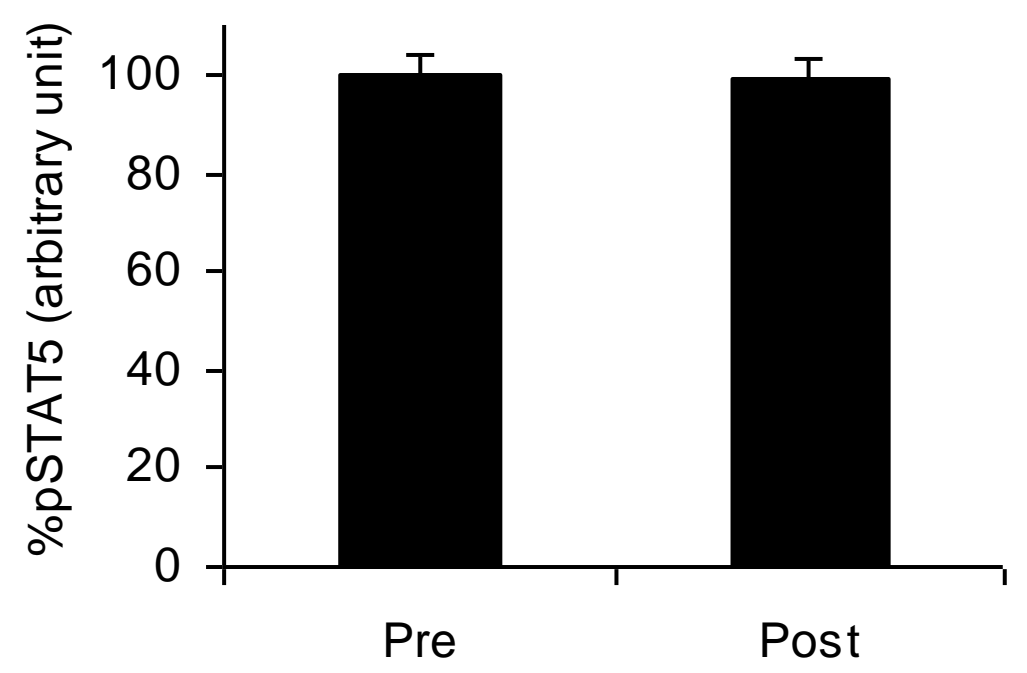

